\title{
A geography of big things
}

\author{
Jane M. Jacobs \\ Institute of Geography, University of Edinburgh
}

\begin{abstract}
This paper sketches some conceptual tools by which cultural geographers might advance geographies of architecture. It does so by thinking specifically about one architectural form: the modernist residential highrise, which is the 'big thing' of this paper. The paper draws on recent developments in material semiotics in order to interrogate features often uniquely associated with the highrise, such as its global reach, uniformity, and scale. The paper first rethinks how cultural geography has traditionally explained the movement of built forms, explicitly turning from diffusionist accounts to the notion of translation. It then offers a reconsideration of the way geographers might think about scale in relation to a 'big' and 'global' thing like the modernist highrise, arguing that scale is produced relationally and in specific contexts. Finally, it offers a template for cultural geographical scholarship which takes seriously the technical work entailed in things, like a highrise, materialising or de-materializing. It does so by way of two illustrative stories: one about the productive social science of highrise suicides in Singapore; the other about the destructive role of the inquiry into collapse of Ronan point in the UK.
\end{abstract}

$\mathrm{T}$ he journal cultural geographies, under this title and previously as Ecumene, has provided flagship scholarship in cultural geography for over a decade. Cultural geographies has played this part in a period that has witnessed both unprecedented enthusiasm for the (now not so new) cultural turn and an emergent scepticism around what cultural geography has come to stand for, specifically its apparent overemphasis on representation. As Catherine Nash and I have observed elsewhere, this new scepticism is evident in a range of cultural geographical writings. For example, the recent Handbook of cultural geography, itself an exemplary account of the vital contribution of cultural geography to the discipline, opens with a picture of a tomb with the epitaph 'Here Lies Cultural Geography, Born 1925, Died 2002. In Loving Memory'. There could be no clearer expression of the peculiar combination of commitment to and disenchantment with the concept of culture in contemporary geography.

It is not the only death wish that cultural geography has had to endure recently. Don Mitchell concludes his review of Mike Crang's Cultural geography with the following epitaph: 'Despite a brief and brilliant beginning, in the end, it never amounted to much.'2 A mere decade ago cultural geography was seen as an analytical frame that could promise not only a productive, but also a necessary, reshaping of geographical scholarship. Now it seems we can't decide if we want this sub-field to be dead or alive! This paper is not a defence of cultural geography per se, nor even an attempt to police the ways in which we might use the term 'culture' in our geographies, although that has been one evident response to the confusion over the value of cultural geographical 
approaches. ${ }^{3}$ It does, however, have something to say about things being alive or dead - and it does presume that the approach taken, in significant and worthy ways, is indebted at least in part to the vital novelty bequeathed by a sub-disciplinary field known as 'cultural geography'. Not least, the paper's focus on building technology and building practices self-consciously resuscitates and extends a theme common to cultural geographical scholarship, old and new.

The scholarship on buildings and building events has taken many forms within cultural geography. The theoretically and methodologically disparate fields of 'geography of settlement', 'urban morphology', 'urban semiotics' and 'cultural politics of the built environment' all scrutinize the built form in one way or another. The earlier versions of such scholarship privileged the materiality of the building, often requiring it to operate forensically as evidence of wider, more abstract processes or morphological conditions. In more recent geographies, the technical and formal qualities of buildings served as a faint skeletal infrastructure for studies more concerned with meaning and the politics of representation. Recent calls for 'new geographies of architecture', while claiming something distinctive, remain indebted both to older artefactual settlement geographies and more recent cultural geographies of meaning. ${ }^{4}$ Energized by the recent emphasis on embodied materialities, they share with older settlement geographies an interest in a building's physical presence: its format and shape, architectural style and construction detail. Of course, in the hands of a 'new geography of architecture' that interest is put to a quite different analytical purpose than it might have been in the hands of, say, a settlement geographer. For example, Fred Kniffen's use of house typologies required material form and technical details to act as proof of evidence of map-able cultural traits. ${ }^{5}$ In contrast, most of the new geographies of architecture claim to be taking a critical stance in relation to the forms they focus on. Often the critical turn of these new geographies of architecture relies upon activating the voice of the user/occupant, in a revision of standard traditions of post-occupancy evaluation in architecture and housing studies. As such, they share intellectual ground with representational geographies in which the building is a sign in a semiotic system of meaning. But they also point to suggestive ways of expanding a semiotic methodology, such that it encapsulates the notion of a 'semiotics of materiality' in which the relational assemblages of human and non-humans that work to 'make' a building event are brought into view. ${ }^{6}$

There are a range of other scholars (some geographers and others who have a geographical readership) whose work engages with the question of architecture, building and buildings, but who, thus far, have not been incorporated into the intellectual lineages constructed for, or future agendas set by, 'new' geographies of architecture. Central to this scholarship is the work of Anthony D. King on architecture and built form. His often-overlooked 1984 monograph on the bungalow, themes from which were recently revisited in his Spaces of global cultures, provided an important epistemological break from the cultural diffusionist accounts of older geographies of settlement. ${ }^{7}$ King tells a remarkable story of a 'global' architectural form that originated in south Asia but, energized by the transnational flows of people, ideas and things facilitated by empire, found its way across the globe. In King's scholarly hands, the 
bungalow was no longer a form that operated as a stable artefact of culture-on-themove. Rather, it was shown to be a worldly and hybrid form that spoke of internationalized networks of professional architects and planners, globalizing taste cultures, transnational labour markets and the imperial trade in technical knowledges and skills. King's work has much in common with a larger body of scholarship, too broad to do justice to in this paper, that deals with the complexly politicized origins and fortunes of specific architectural styles as they make their way into various visions, be they utopian, futuristic, nostalgic, nationalistic, colonial or postcolonial. ${ }^{8}$ Such scholarship has in common an interest in the ways in which certain architectural forms come to be in certain places. As such, they provide critical accounts of a wider field of 'construction' (sometimes material, professional and technical, but also discursive), and model suggestive trajectories for how we might reconceive of the making and movement of built forms in space and time. In this model of a geography of architecture, the building and how it is made does not simply operate as the evidentiary field for a story about the cultural typology of settlement patterns. Rather, the objective is to investigate the processes by which certain things cohere to produce 'building', 'architecture', 'housing'. In this sense, these studies effectively broach the question of how a building comes to have 'presence', how it is stitched into place by fragmented, multi-scaled and multi-sited networks of association. ${ }^{\text {? }}$

I would like to investigate these themes by way of a specific type of architecturebuilding-house: the modernist, state-sponsored, residential highrise. This is the 'big thing' of this paper. Of course, I might have more accurately called it a 'tall thing', or even perhaps not worried about 'sizing' it or 'thing-ing' it at all, and simply called it a building, an urban form, a style of settlement, or housing. By using the term 'big thing' to describe the highrises I want to forestall the constructivist force of those more coherent terms like architecture, building or housing, a force that predetermines specific understandings as it precludes other kinds of knowing. Commenting in passing on what might distinguish a 'geography of things', Philo draws on Baudrillard's prescribed technique for a 'surface accounting' of the 'goings on of the thing-realm'. Through this technique it is possible to see that a seemingly minor thing like a 'toy rabbit' lies on the same level as 'advanced capitalism' ${ }^{10}$ By dubbing the highrise a 'big thing' I am establishing the preconditions for engaging in this exercise of 'surface accounting'. An interest in surface does not mean a disinterest in the wider systems in which a 'thing' is entangled (be they systems of production, inhabitation, valuation or dissolution). ${ }^{11}$ Rather, it is to bring into view how the coherent given-ness of this seemingly self-evident 'thing' is variously made or unmade. Further to that, I seek to demonstrate the part played by the constitution of scale in relation to stabilizing this 'big thing' called the highrise. At a very cursory level we might, by way of example, observe that it is not simply the physical size of the highrise that allows it to claim a status as a 'big thing'. The residential highrise has been variously drawn up into a range of indisputably big stories and organizational events: utopian visions for living, stellar architectural careers like that of Le Corbusier, bureaucratic machineries of mass housing provision, national projects of modernization, the claims of critical social sciences and spectacular instances of failure, as well as popular and academic imaginaries about 
globalization. These stories and events are components in the networks of association that work to keep this form in place or to pull it apart - that is, they contribute as much to its thing-ness as they do to confirming something we might think we know about its scale. It is stories of how buildings like the highrise stay assembled or come apart which form a key focus of the research from which this paper is drawn.

\section{Fitting big things into the story of geography}

In a recent article in the Professional geographer, entitled 'The big questions in geography', Susan Cutter, Reg Golledge and William Graf responded to a challenge laid at the feet of professional geographers by a New York Times science correspondent, John Noble Wilford, at the 2001 AAG opening session. Wilford called for geographers 'to articulate the big questions in our field'. Their response flags a series of big geographies already under way: geographies of global warming; geographies of natural and technological hazards; Geographical Information Systems that, post-9/11, can contribute to what they term 'emergency preparedness and response'. Their paper also suggests a range of other 'major issues' to which we might turn our attention. ${ }^{12}$

There is in this statement of the discipline's 'big questions' and 'big future' just two, perhaps unsurprising illustrations: before-and-after photographs of the Twin Towers of the World Trade Centre (Figure 1). In the image that shows the towers standing, the towers are so big (or so tall) that they cannot completely be captured by the limits placed on the image (be that a limit placed by the position of the photographer, the field of vision of the camera lens or the constraints of journal page layout). The towers are decapitated. The companion image shows the towers gone, and in this page layout
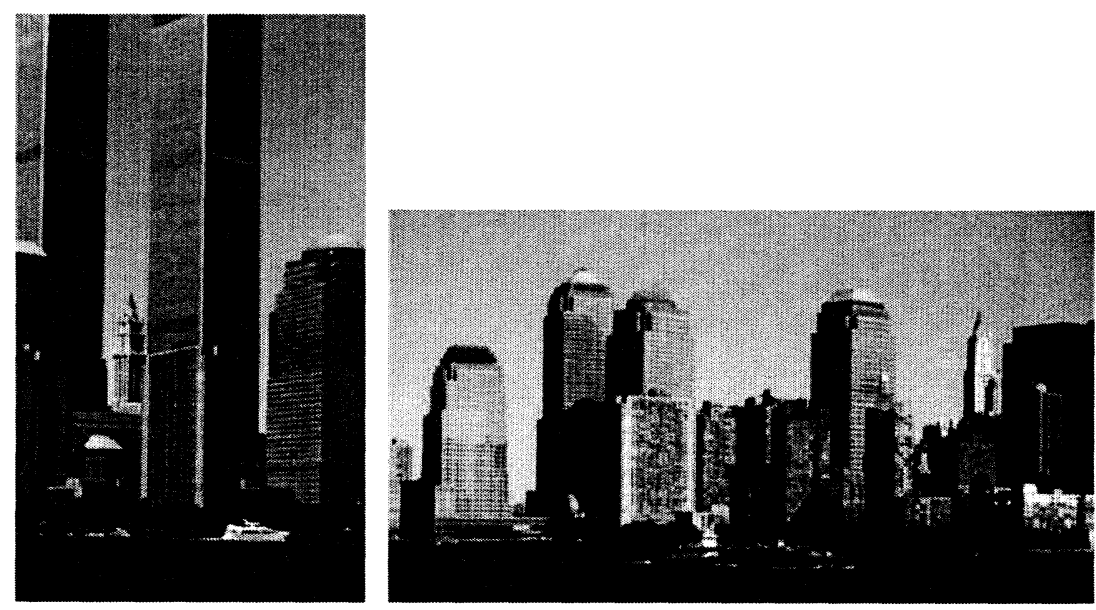

FIGURE 1 A recent 'before and after' illustration of the World Trade Centre showing this 'big thing' both in and out of the skyline of New York City. (Source: S. Cutter, R. Golledge and W.L. Graf, 'The big questions in geography', Professional geographer 54 (2002).) 
they are so 'not there' that the image itself does not even attempt to capture what Christine Boyer has described as 'the wounded skyline'. ${ }^{13}$ The squat picture, full of the buildings left behind, crops out the very absence that is at the heart of this picture. On the one hand, these towers and their destruction is all-important to the 'big questions' and the 'big claims' made in this prescriptive, future-oriented piece. On the other, their thing-ness (or lack thereof) is handled awkwardly, incidentally. If, as Ada Louise Huxtable noted in her essay The Tall building artistically reconsidered, "The tall building probes our collective psyche as it probes the sky', then what might these two seemingly incidental companion illustrations say to us? ${ }^{14}$ Why is it so hard to represent these big things - be it in their presence or their absence - and so easy to scope in prescriptive detail the 'big' geographical research agendas that their fate helps bring into view? ${ }^{15}$

The tall building - be it a skyscraper or its ambiguously located relative the residential highrise - has been of concern to cultural and urban geographers in varying ways and for some time. Cultural geographers directly or loosely tied to a North American tradition of settlement geography often turned to the tall building as an example of a modern stage in the evolution of human settlement. Pick up one of the broad-sweep human geography textbooks of the 1960s and 1970s from North America, and you are likely to see a picture of a residential highrise - sometimes used to illustrate the most recent phase in the evolution of human settlement types (buldingsin-time) and sometimes used to illustrate the diffusion of housing types (buildings-inspace). ${ }^{16}$ Of course, French urban geographer Jean Gottmann (1915-94) was pursuing just such questions about settlement type and spread when he asked in 1966 in the pages of Geographical review, 'Why the skyscraper?' For Gottman, inquiring after a specific building type was any thing but 'superfluous' to developing an understanding of wider processes of North American urbanization. For him the skyscraper was 'an important geographical phenomenon'. To paraphrase Gottman, it is through the skyscraper that we 'get into geography': formulas in land use, economic activity, landmarks, skylines and urban landscapes. ${ }^{17}$ Gottman is, in some respects, belatedly answering the call of architect Louis Sullivan, who in 1896 wrote in 'The tall office building architecturally considered': 'The problem of the tall building [was] one of the most stupendous, one of the most magnificent opportunities that the Lord of Nature in His beneficence has ever offered to the proud spirit of man. ${ }^{, 18}$ Of course, geographers of various kinds have returned to these questions from quite distinct, more up-to-date and perhaps more modest perspectives. In the 1980s Mona Domosh took the insights of a newly invigorated cultural historical geography to work on the first skyscrapers of New York, among other things charting the picturesque imaginations and ornamental embellishments that stitched this form, with all its novel scales and technologies, into place. ${ }^{19}$ Similarly, and drawing on over two decades of thinking, Larry R. Ford has turned to the skyscraper as one of three indicative forms of contemporary urbanism in his aptly titled Cities and buildings. ${ }^{20}$ That book captures a specific passion for the thing-ness of buildings consistent with cultural geographies old and new. Ford prefaces it with a reflection on why he writes his geography through a consideration of architecture and buildings. He does so out of his own fascination with and belief in the 
explanatory power of small things: what he calls the 'nooks and crannies' of his urban world. In this context, he refers to the specific inspiration delivered by a character in a James Thurber story whose daily struggle was with sockets that she feared might leak electricity all over the house if left switched on. Larry Ford's own accounting of the big thing called a 'skyscraper' does not get as close to such micro-geographies as we might hope. His concern with the 'nooks and crannies' of the skyscraper quickly gives way to bigger explanatory frames, testifying to the compelling force of that other scale, represented as it is both through mass itself (height) and logics of massification (repeated instances). For Jean Gottman the sheer multitude of instances of tall buildings was one of its most distinctive features, and in urgent need of geographical investigation. It was, he said, 'a phenomenon that is spreading all over the world, to the point where it has become typical not just of American cities but of the architecture of our time'. And he goes on: 'As the skyscraper has spread to other continents, one may even wonder whether it still has the same meaning and function it had in the beginning. ${ }^{21}$ Anthony King, in a continuation of his scholarship on the global geographies of architecture, has more recently tackled the worldwide fascination with tall buildings and accounted for what he terms the 'symbolic functions of architectural gigantism' in 'a globally competitive display of economic virility and political power'. ${ }^{22}$ His account ties the tall building into big geographies of economic and cultural globalization, while at the same time registering the differentiated field in which it is produced. As King observes, "the "global" meaning of a highrise tower, a public housing project, at any particular site in the world, will be de-coded and recoded, invested with a myriad of different interpretations' ${ }^{23}$ The approach outlined in this paper shares something with both of these perspectives. It shares with Ford a fascination with the nooks and crannies of building technology and suggests that such minor matters might play a more substantive evidentiary role in what has been dubbed 'geographies of architecture'. At the same time, and following King, it seeks to bring into view the ways in which these technologies actively work to stitch these buildings into big stories of various kinds.

I have thus far in this overview of past geographies of tall buildings glided between the residential highrise and the skyscraper as if such smooth passage is possible just by dint of the shared feature of scale. But, of course, the (mainly) commercial skyscraper and the residential highrise are only distantly related forms. Indeed, nowadays we would assume that the state-sponsored residential highrise was but a poor, lost cousin of the skyscraper. Such a positioning varies markedly from what was imagined in the early twentieth century. As Rem Koolhaas notes, when Le Corbusier was devising his vision for a modernist residential highrise - his 'Cartesian skyscraper' - he was nothing but bothered by New York skyscrapers. Le Corbusier disapproved of them, dubbing them 'infantile' and 'too small'. His own vision for the 'Cartesian skyscraper' was something taller, stripped of ornament and, by way of his 'anti-Manhattan' urbanism, in settings more open and spacious. ${ }^{24}$

It is the varied fortunes of Le Corbusier's 'Cartesian skyscraper' that is the specific focus of this paper. This form and its utopian urbanism came to be embedded in varying ways in varied settings, in a project of mass housing provision. In the 
massification of highrise living solutions, Le Corbusier's skyscraper became fully entrenched in a bureaucratically managed process wherein modernism and modernization came together to form what Paul Rabinow has usefully termed a 'middling modernism'. ${ }^{25}$ The research project from which this paper draws seeks to chart the varied afterlives of the residential highrise as a thing with a 'global' effect. The repetitious form and mobile habit of the residential highrise readily sustains various discourses about the homogenizing effects of globalization, and specifically a rationalist, Western practice of architecture and urbanism that has colonized diversity and difference. ${ }^{26}$ Appadurai has advocated the adoption of a 'process geography' in order to understand globalized circumstances. ${ }^{27}$ A process geography would allow us to 'name and analyze ... mobile civil forms' and to chart 'various kinds of action, interaction and motion', underscoring the global. Analytical prescriptions such as these attempt to bring into view 'the global everyday' wherein the nuanced and differentiated lived experience of the 'global effect' is registered. ${ }^{28}$ Such scholarship attends to the 'conditions of possibility' of global movement. Including how knowledges and technologies move through transnational professional and administrative structures, and requires what Collier and Ong have called a 'technical criticism' ${ }^{29}$

Within the contours of repetition that seem to define the highrise, there exist important logics of differentiation. We might, very straightforwardly and within the frame of big history, for example, note that this global form came to be so 'everywhere', so international, because it was incorporated into a range of settings in the name of local, specifically nationalist and often postcolonial enthusiasms. From the outset the highrise was both a mark of becoming modern (more civilized, more international) and a mark of becoming different (independent, not colonial). ${ }^{30}$ Similarly, we might note that this form eventually did not fare too well in other, some might say originary settings, such as in the United Kingdom, where nowadays local social housing authorities ponder what to do with highrise stock and often determine that demolition is the only viable option. Looking at divergent national conditions of success or failure as a way of complicating or undermining a story of globalization is only one deconstructive strategy available. One might also look towards the relational work that allows this form to flourish in one setting and to languish, perhaps even collapse, in another. That type of scholarship has at its heart the commitment to thinking in a minor way - taking seriously the detours, the fine-grained detail, the exception, the 'nooks and crannies'.

In a recent review article on 'Skyscraper geographies' Donald McNeill suggests that the skyscraper is a form whose 'substantial impact on ... urban life' has been neglected. ${ }^{31}$ The same could not be said for the tall things that middling modernism produced. The highrise mass housing visions of both developed and developing countries created quite different lives, and called into being a plethora of geographical and sociological scholarship. The new densities and logics of everyday life in these buildings - coupled with the deprivation that often coincided with this housing - was a worry for bureaucrats and academic experts alike. The full scope of this scholarship is too great for me to summarize here, but I will return to some of it in the course of this paper. Sometimes this scholarship was 'inside' the system of provision of 
highrise housing itself (such as post-occupancy studies) and sought to shore up the fact of highrise living; sometimes it was 'outside' it (such as critical academic accounts) and questioned its sense. We might think here of studies of the ill-effects of density coming out of an emergent discipline of environmental psychology, or of Oscar Newman's study of crime and fear in highrise project housing in New York, or of British geographer Alice Coleman's trial of the highrise 'utopia', or of sociologist Chua Beng-Huat's longitudinal study of the impact of highrise housing on Singaporeans re-housed from kampongs. ${ }^{32}$ We might think of such studies, following Paul Rabinow, as modernizing 'tools' in and of themselves, in that they work to analyse the needs, forms and norms of highrise life. ${ }^{33}$ These sociologies and geographies sometimes work to shore up such highrise forms; at other times they provide critiques that eat away at their very foundations.

It was the critical vein of this scholarship that provided at least part of the evidentiary field upon which contemporary revisionist, Western planning and architecture has been built. The highrise was the form to which a tightly scripted story of the life and death of the monster of modernist planning and architecture attached itself. An illustrative version of this scripting is provided in Leonie Sandercock's Towards Cosmopolis. ${ }^{34}$ Here Sandercock rehearses a now familiar argument about modernist architecture, urban design and planning: how it radically 'decontextualizes'; how it denies 'history and everyday life rhythms'; how it places mind over body; how it results in 'shock' and 'defamiliarization'. ${ }^{35}$ In this script of a modernist city there is a special place not only for the tall building but also for certain notions of governance. It was the expert (architect, planner, engineer, bureaucrat) who was to oversee, quite literally, from their centralized towers, the running of whole cities and nations. Sandercock, like others before her, gives Le Corbusier the role of father inventor in this script. According to Sandercock, he worked only to the 'manifesto of the straight line' and indulged always in a 'masculinist fantasy of control'. ${ }^{36}$ Le Corbusier himself positioned the tall building as integral to the imagined future. The tall buildings were to 'embody the work of elaboration and command on which all activities depend'; they were to be the 'brain of the City'. 37

Sandercock's book includes a commissioned image by photographer Peter Lyssiotis that gives this scripting of modernism explicit expression (Figure 2). Here the terra firma of modernization belongs to the straight-lined rationalist highrise (tended by its white-coated experts), while tradition, real ornament, sacredness, the organic, appear only as a shimmering reflection in the nearby waterway. It would seem that this modern form, and all that it stands for, had successfully had its way with the city of diversity, displacing difference, the feminine, bodies, personalities, local contingency. A building type that was inaugurated as an invitation for the masses to inhabit the city as fully housed urban citizens has come to be understood as a malevolent monster, which offers nothing more than uninhabitable spaces from which tradition, real ornament and community are banished. Sandercock, of course, is not alone in this view. The highrise was put to similar use by Prince Charles (the Prince of Wales) in the late 1980s when he proposed his Vision of Britain. ${ }^{38}$ Here an entire revisioning of British architecture and planning (both rural and urban) is rhetorically grounded upon the failure of 


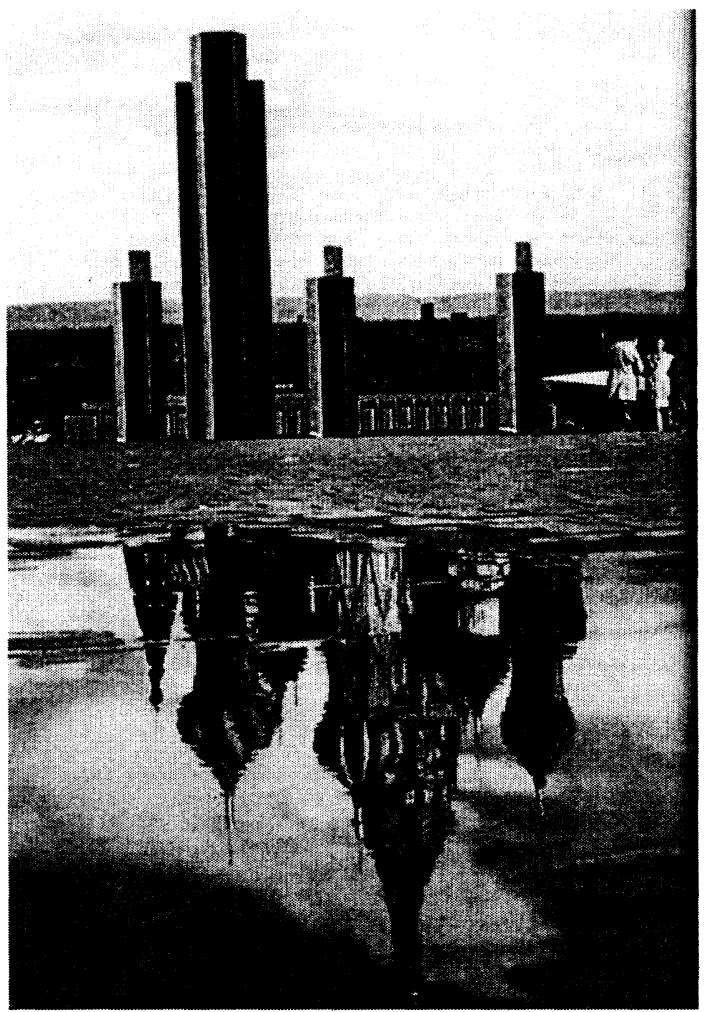

FIGURE 2 A photocollage used in Leonie Sandercock's Towards Cosmopolis (1998), which illustrates how the highrise is scripted into the binarized structure of revisionist planning discourses. (Photocollage reproduced with permission of the artist, Peter Lyssiotis.)

the highrise modernist form. With a rather more global reach, architectural commentators like Charles Jencks have referred to the planned demolition of Pruitt-Igoe (1972) and to the unplanned collapse of Ronan Point (1968) as symbolic markers of the death of modernism and the beginnings of postmodernism, which, in architectural terms, was the 'post' which brought back history, tradition, locality and wiggly bits $^{39}$ (Figure 3).

\section{A baroque geography of a modernist big thing}

In a recent article on the city, Nigel Thrift captures something of the problem contained within such revisionist interpretations of modernism and modernization. Thrift argues that cities are not mirrors of modernity; they are, rather, 'not a straight line but a curve'. ${ }^{40} \mathrm{He}$ is generally sceptical about terms like 'modernity', which, he suggests, adopting the language of Latour, are dangerous and tend to 'write in' the West as 'the 


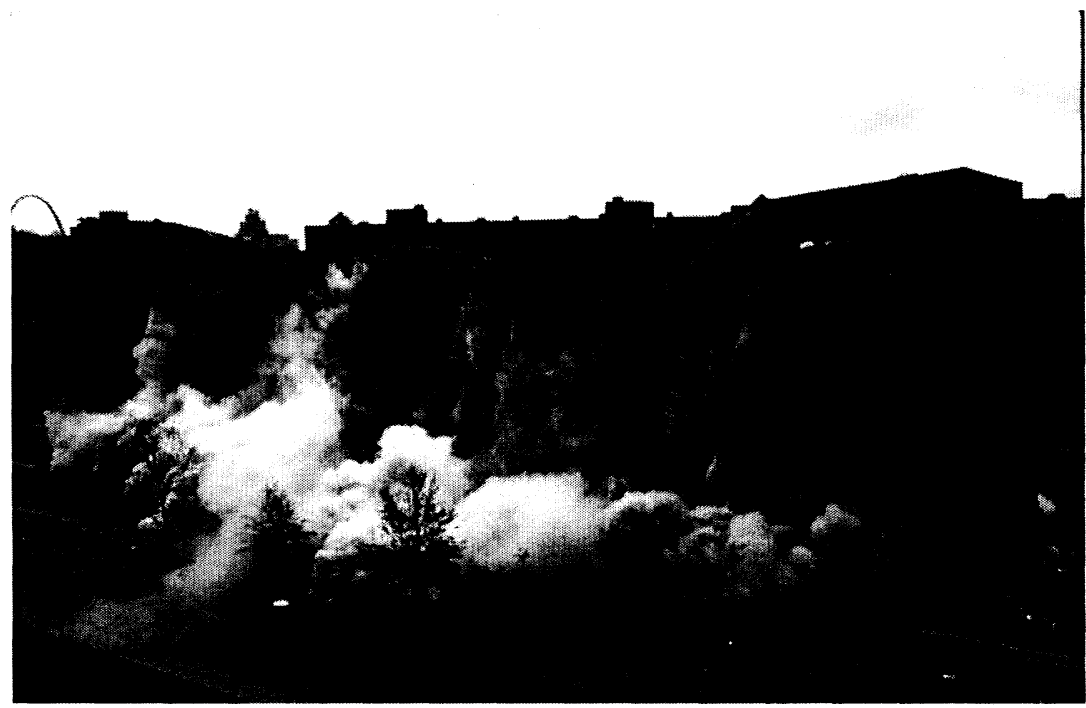

FIGURE 3 The now emblematic image of the planned destruction of Pruitt-Igoe, an event Charles Jencks dubbed as marking the 'end of modernism'. (Source: Getty Images, Time and Life Pictures, photographer Lee Balterman.)

stuff of saga ... fatal destiny, irreversible good or bad fortune'. ${ }^{41}$ Thrift identifies four persistent myths about cities: that all cities are instants in a global space of flows; that cities are becoming homogenized; that cities (or parts of cities) are inauthentic; that one city tells all. Thrift is taking us to where he has been going for some years now intellectually: towards a conception of the city that is formed out of a 'set of diverse and interacting practical orders' which are 'formed, maintained and changed' by what he terms 'networks of associations between unlike actors'. These networks of association are never completed: they are always in a state of being made or unmade by what he calls, again following Latour, 'constant semiotic-cum-material work'. ${ }^{42}$

An analytical context such as this is evident in recent calls for a new 'critical geography of architecture'. This work provides suggestive ways for rethinking geographical scholarship on built forms. In the first instance, it asks geographers to get up close to buildings as occupied performative events. Loretta Lees, for example, argues that a 'critical geography of architecture must be able to engage with those embodied and socially negotiated practices through which architecture is inhabited' ${ }^{43}$ Mark Llewellyn, similarly, has gone inside the relevant case of the early modernist Kensal House, London. Through interviewing original residents about their experiences of living in this architect's vision, Llewellyn extends conventional post-occupancy studies, and creates new analytical dialogues between the voices of inhabitants and the voices of 'inventors' in order to chart the messy co-production of lived geographies of domestic modernity. ${ }^{44}$

Similarly suggestive is Lloyd Jenkins's geography of the architecture of 11 Rue du Conservatoire. Jenkins argues again that geographers have thus far 'failed to fully 
appreciate the complex nature of an individual building', and asks that the building and its use be seen together. ${ }^{45}$ Drawing on the sociology of science and technology, Jenkins asks how we can conceive of a building as something other than a formal space, a form known primarily by its boundaries. He argues that traditional accounts of buildings tend to take for granted what their limits and boundaries are - they have formal qualities, they have edges and walls and windows, they are 'there'. In so doing traditional geographies have 'black-boxed' the building: 'They all treat the individual building as a blank canvas on which another discourse is illustrated. ${ }^{46}$ They do not interrogate the socio-technical processes by which that there-ness materializes: the process of construction and use of the building, the various modes of authorship and ownership, the day-to-day complexities of maintenance and servicing. Jenkins concludes: 'Instead of simply treating buildings as stable, safe, and static black boxes on which we can hang our arguments and claims ... we need to dispel the myth of buildings as being static, closed, and materially constant. ${ }^{47}$ Jenkins makes two significant moves in this respect. In the first instance, he argues that simply attending to the views and movement of social actors through space, although going some way to opening out the geographies of architecture, does not do enough. Indeed, it is very likely that such an analytic move reinstates the social as if somehow other to and more than the building. In working away from this dilemma Jenkins draws upon the work of John Law and Annemarie Mol, who argue forcefully for the co-production of the material and the social: when we look at the social, we are also looking at the production of materiality. And when we look at materials, we are witnessing the production of the social. ${ }^{, 48}$

What Jenkins's detailed study of 11 Rue du Conservatoire does is complicate the idea of the building, not simply by talking with or watching users, but by thinking about the diverse fields of relations that hold this building together over time and in space, including pipes and cables, managers and users, owners and investors. In this study the materiality of the building is a relational effect, its 'thing-ness' is an achievement of a diverse network of associates and associations. It is what we might think of as a building event rather than simply a building. ${ }^{49}$ Conceived of in this way, a building is always being 'made' or 'unmade', always doing the work of holding together or pulling apart.

The kind of thinking going on under the banner of 'new geographies of architecture' reminds us, first and foremost, that the term 'architecture' itself is problematic. As Stewart Brand notes, that term attaches a whole range of assumed lineages and fortunes to the material assembly that is a building. ${ }^{50}$ To designate a built form as 'architecture' immediately assumes certain things about its making (for example, that there is a designer), the nature of its presence (for example, that it has stable formal qualities which tell us what it is), and how it is received (for example, that it is 'design' as opposed to something else). In this sense, the first steps of a truly critical geography of architecture would be to speak about the claims building events make on the ideas and practices of architecture: how those claims are assembled, how they materialize and help the form to materialize in specific ways, and how they come to operate in relation to a range of non-architectural others. In short, it would require us to think 
critically and up close about how a professionalized architecture works to sustain itself (or not) as an authoritative practice in relation to building events, and how building events are or are not 'architecture'. ${ }^{51}$ We might usefully here consider the example of the mass-produced residential highrise and compare it with the signature skyscraper by the named architect. In the latter building event the architect-as-inventor/designer is clearly in place and determines much about the building's biography. But in the anonymous and bureaucratized middling modernism of the mass produced residential highrise the architect is buried deep in the institutional framing of, say, the London County Council or Singapore's Housing Development Board. Indeed, Rem Koolhaas, in his manifesto on size, $S M L X L$, has argued that one good thing about 'bigness' is that it produces what he refers to as a 'regime of complexity' in which the architect and architecture are necessarily placed into conversation with other fields. Big buildings, he argues, cannot be controlled by a single architectural gesture, or even a combination of gestures. ${ }^{52}$ Bigness, he concludes, 'is where architecture becomes both most and least architectural'. It appears most architectural because of the scale, but in achieving that scale the big thing has to be less architectural because there is a loss of autonomy. It becomes, as Koolhaas puts it, dependent - 'an instrument of other forces'. For a building to take form and sustain itself as a big thing, it must 'surrender to technologies; to engineers, contractors, manufacturers; to politics; to others'. 53

If we start to subject the big thing called the residential highrise, and its 'global story', to this type of analytic lens, then what comes into view? First, we might begin to see past the building as a formally defined thing, and see instead the array of allies that the highrise form has to harness in order to be formed and to function. Secondly, this lens enables us to register the fact that the resident - although from some perspectives the most important component in a building - is just one of many components, human and non-human, that constitute the building event. The building thing is not a passive context, nor even a fully determining parameter, for the resident/user. The building thing is, as Elizabeth Grosz puts it, 'both a resource or raw material for human action, and the product or construct of the living'. As Grosz's pragmatist reading of things reminds us, 'we make or fabricate the world of objects as an activity we undertake by living with and assimilating objects' in a mode of 'continuous experimentation'. ${ }^{54}$ Finally, as geographers we can undertake scholarship that uncovers the work that makes the building appear as a 'black box', a coherent thing in itself. A matter I turn to in the context of thinking about how the highrise has 'gone global'.

\section{The highrise as a global thing?}

When thinking about a building type that has 'gone global', as the residential highrise has, then we need to decide how this has happened. How does something like a built form 'go global'? Is this a story of spread, akin to the diffusions through time and space that settlement geographies so carefully charted? Or is it something else? Piers Blackie once called diffusion a 'spacious-cul-de-sac' in the history of geographical thought. ${ }^{55}$ Indeed, few left in the discipline of geography would 
conceive of the work of cultural geography to be the charting of built forms as artefactual evidence of the movement of cultural traits through time and space, let alone imagine that a study of a global cultural form such as the highrise should account for this through a model of diffusion.

I have already flagged King's scholarship on the global proliferation of, say, the bungalow or the drive to build the tallest building. In his early work, King called upon the power of World Systems Theory to explain the global effects he saw manifest in a global culture of architecture. In his more recent work he has turned, albeit with some reservation, to a more diversified postcolonial model of multiple modernities. As useful as these broad-brush explanations are, they often fail to grasp the lived event of how something comes to be everywhere. Despite intentions, older diffusionist narratives can continue to haunt these seemingly more progressive explanatory frameworks, carrying with them the familiar spectres of geographies of cores and peripheries, trajectories of here to there, and structures of originary and variant objects.

The problem of the persistence of diffusionist explanations for how things replicate themselves (be it an invention, a machine, an idea, or even a building technology) has preoccupied science and technology studies for some time. For example, Bruno Latour's concept of 'translation' was developed specifically as a critical alternative to diffusionist story-making. Diffusionist models of explanation have a relatively stable thing moving through space and time by way of social effort. Translation, in contrast, brings into view not only the work required for a thing to reach one position from another, but also the multiplicity of add-ons that contribute, often in unpredictable and varying ways, to transportation. The concept of 'translation' brings back in not only the 'forgotten ... many' who carry things 'from hand to hand' but also 'the crowds of acting entities' that shape the affiliations that form around a thing on the move, and thereby contribute to how coherent and convincing that thing remains or becomes. ${ }^{56}$ Thus the story of a thing that moves 'may be analysed either by looking at the changing shape of the [thing] - tied to different people - or by looking at the changing type of people - linked to the [thing]. It is the same story. ${ }^{57}$ This kind of scholarship attends to what Thrift calls the 'little things': 'mundane objects like files, mundane people like clerks', or even a seemingly mundane material like cement, that work to ensure that when an idea like a highrise arrives in a place it is seen as something to rally around, build, maintain and live in. ${ }^{58}$ It is this work that allows a thing like the highrise to appear as a global form - to have a global effect.

In a recent paper, John Law observes that the global is always taken to be 'large, as large as could be on earth'. It is also taken to mean complexity, and specifically complex interaction. Law stands back from these assumptions and asks whether it is possible to think of the global as 'small' and 'non-coherent'. ${ }^{59}$ In seeking an answer to that question he suggests we need a 'baroque' understanding of the global. This would beckon us not to 'look up' towards the broader picture, but to 'look down' at the detail. A baroque imagination 'discovers complexity in detail or specificity, rather than in the emergence of higher level order, ${ }^{60}$ A baroque sensibility reminds us that a seemingly global thing - like the residential highrise - is always at the same time situated and specific. This kind of reasoning has particular ramifications for the question of scale 
more generally. Scale, Law says, is specific to each location: 'if [something] is bigger or smaller then it is because it can be made bigger or smaller at this site or that.' Put briefly, size is a 'specific accomplishment' and not something that is 'given' ${ }^{61}$

If we apply this thinking to the 'big thing' of the residential highrise, then it implies that global effect is the result of specific 'work' in distinct contexts. The surface effect of sameness and everywhere-ness that the residential modernist highrise carries with it is really based on a 'chaotic morphology'. ${ }^{62}$ Relatedly, we can note that the big story of global convergence into which the highrise form is routinely drawn - as in the story of revisionist planning told above - can only be sustained if there is a wilful disregard of the differences that were at work to give rise to the apparent repetition. Finally, the baroque sensibility treats the global as specific and this radically alters how we can think about scale: as Law puts it, 'Big and small, local and global, these are being made in this way here and that way there. ${ }^{63}$

In the last part of this paper I want to get 'up close' to the residential highrise in two specific settings - Singapore and the UK. I do not get up close through an ethnography of a current building event. Rather, I want to look closely at the residential highrise by way of the archive it has produced. That archive provides fruitful evidence of the relational work that has allowed the highrise to continue to flourish in Singapore while it languishes and, in the case of some social housing variants, even starts to disappear in the UK.

\section{Alternative modernities: a story about how big things hold together ${ }^{64}$}

The post-independence housing programme of Singapore, administered from 1959 onwards by the Housing Development Board (HDB), is a well-known example of commitment to highrise housing. The distinctive HDB schemes structure the visual and experiential morphology of much of Singapore. Singapore's housing programme was a fundamental component in the enthusiastic making of a post-independence nation. This kind of enthusiasm - in this case for housing modernization - has been described within postcolonial theory as an example of the 'rage for modernity' ${ }^{65}$ Such enthusiasm, is it argued, provides evidence of the ways in which modernity is not something that simply travels out from the West, to be thrust upon unwilling recipients. Rather, the modernisms and modernizations of, say, Singapore may well evidence what has been dubbed an 'alternative modernity'. ${ }^{6}$

In post-independence Singapore the state actively claimed modernity (and the modernist architectural style) for itself. Through the HDB's mass housing programme it is possible to see a whole range of localized innovations and animations that subjected the high-density highrise form to its own modernizing agendas as much as that form, and the mechanisms of governance that supported it, may have subjected the people who came to live in it to logics of the modern. In the case of the highrise in Singapore we can see how modernity, far from being imposed on docile and fragile native cultures, is adopted, adapted and transformed with great vigour. As Gaonkar argues, 
'people "make" themselves modern, as opposed to being "made" modern by alien and impersonal forces'. ${ }^{67}$

It would be wrong to imagine that the enthusiastic embracing of the highrise housing solution in Singapore was without local critics or local resistance. There was, from the outset, considerable disquiet among ordinary people and critical experts about the possible inappropriateness of highrise living. Key among these concerns was a worry about the emotional disorientations that might be produced by a loss of sense of place and changes in scale. This was a local variant of a wider-felt concern - held in both First World and developing contexts - with the psychic (and other) ill-effects of living in 'anonymous' and 'standardized' high-density and highrise living environments. In the Singaporean context, a specific worry emerged around the increased incidence of a new and spectacular mode of suicide in which victims jumped from the heights of their newly built housing estates. How, in all this rage for modernity, might a socio-psychic phenomenon like the 'highrise leap', as it became known, be accounted for? This spectacular mode of suicide produced specific difficulties for a state trying to impress upon its citizens, and the rest of the world, that it was a modernization success story.

Concern around the 'highrise leap' generated a good deal of sensational and expert story-making. From the outset, the investigations of the highrise leap were conducted in a way that sought to assess whether there was an explicit causal link between modernization, and the highrise built form that was becoming its most quotidian expression, and the increased incidence of leaping. This question became the central preoccupation of one particular scholar - sociologist Riaz Hassan - who, during his time as a member of staff in the sociology department at the National University of Singapore during the 1970s, undertook a number of studies on the social and psychological effects on Singaporeans of being housed in high-density highrises. ${ }^{68}$ Hassan brought to this work not only the legacy of Durkheim's original sociology of suicide, but a training in North American urban ecology. In one of his earliest studies of suicide, he looked at files from the coroners' courts for a one-year period. He observed that suicide was associated with specific areas of residence in Singapore, and concluded that $\mathrm{HDB}$ flats had the highest suicide rates of all residential types in Singapore. Furthermore, the methods of committing suicide were strongly related to the types of residence of the victim, with leaping from a highrise being a common mode of suicide. For the purposes of this study Hassan developed a 'worry index' (Table 1). Using this index, Hassan found that people who live on the higher floors experience more stress and strain than those living on the lower floors. As Hassan found living environment to be a determining factor in mental wellbeing, it is not surprising that he suggested that those diagnosed pathologies could be dealt with by adjusting attributes of that environment. The implication of this kind of scholarship was that Singaporeans (citizen and state alike) needed to pursue a new level of care in terms of managing the 'limits' of their newly acquired domestic spaces.

Hassan's analysis no doubt reflected the actual shock (and worry) felt by many Singaporeans as they made the transition from kampong, slum and squatter settlement to highrise. But his scholarship was also a reflection of scepticisms emerging in relation to this form in the West, and specifically in the cross-disciplinary field of behavioural 
TABLE 1 Hassan's 1975 calculation of the relationship between intensity of worry and floor level inhabited. (Source: R. Hassan, 'Social and psychological implications of high population density' (University of Singapore, Department of Sociology Working Paper 47, 1975), p 12. Also reproduced in R. Hassan, Families in flats: a study of low income families in public bousing (Singapore, Singapore University Press, 1977), p. 134.)

\begin{tabular}{lllll}
\hline Floor & \multicolumn{2}{l}{ Worry index } & & \\
\cline { 2 - 3 } & Low & & High & \\
\cline { 2 - 3 } \cline { 5 - 6 } & No. & $\%$ & No. & $\%$ \\
\hline $1-5$ & 19 & 42 & 28 & 37 \\
$6-12$ & 26 & 58 & 48 & 63 \\
Total & 45 & 100 & 76 & 100 \\
\hline
\end{tabular}

ecology, which, under the press of evidence of highrise pathologies, was in the thrall of a form of environmental determinism. If we think in terms of some of the theoretical concepts I have outlined earlier in this paper, then we can see that the relatively occasional, if spectacularly tragic, events of highrise leaping, and Riaz Hassan's sociological accounts of them, produces a challenging 'detour' to the idea of the highrise as a perfect housing solution for a modernizing nation. If those events and that scholarship were to have been taken seriously - to be seen as irrefutable facts about this built form - then it might well have been the basis of a 'big story' that entirely interrupted not only the course of modernization in Singapore but its emergence as a key site in the crafting of the 'big story' of globalization, into which the highrise is routinely drawn.

It was in part to challenge the kind of scholarship represented by Riaz Hassan, and to clarify any 'malicious misconceptions' that might persist around 'Singapore suicide', that in 1980, Chia Boon Hock (supported by the Southeast Asian Medical Information Centre) conducted a comprehensive study of suicidal behaviour. ${ }^{69}$ This study gave an alternate narrative to the presumed relationship between the nature of suicide in Singapore and the rise of highrise living. It could not deny that, in Singapore, by the time of the study, leaping from highrise buildings was the most common method of suicide, accounting for some 42 per cent of suicides. ${ }^{70}$ Indeed, the report even identifies the highrise leap as a method of suicide particular to Singapore, with Chia concluding that 'nowhere in the world is this method so frequently used'. Chia, however, pointedly replaces the deterministic causality that Hassan posed with a far more casual relationship between mode of suicide and mode of dwelling. In Chia's view, the rise in the incidence of suicide by the 'highrise leap' is best explained by three facts: availability, accessibility and fashion: 'As the percentage of the population living in highrise flats increases, there is a parallel increase in the percentage of suicides by leaping. ${ }^{71}$ In this second stage of suicide scholarship the highrise form was now only modestly implicated by mere correlation in the distinctive character of Singaporean suicide. 
These expert studies offered strategies for managing not only a specific Singaporean sociopsychic problem but also the problem that that these negative symptoms (and most certainly that unrestrained act of the 'highrise leap') caused for the national narrative of Singaporean housing success. Through this scholarship the 'highrise leap' was rendered a small and incidental fact about modernization in Singapore. This later and 'more accurate' sociological accounting of highrise living ensured that the highrise form, rather than having its viability challenged, came to be more securely enmeshed in the Singaporean modernization project. In this example, social science becomes, ultimately, an ally of the highrise form. Indeed, the history of highrise housing provision in Singapore is heavily populated with social scientific accounts of highrise quality of life, and for many years the HDB sponsored much of this scholarship itself in the name of 'improvement' and 'innovation'. As such, this scholarship, even when critical, often came to be incorporated in the systems that not only sustained but ultimately enlarged highrise housing, such that today Singapore leads the way internationally in what is now called 'supertall living'.

\section{Artefactual modernities: a story about how big things fall apart}

The second example I wish to explore by way of illustration encapsulates what we might term an artefactual modernity, an instance wherein the highrise idea loses allies, and survives poorly and often in spite of that orphaned condition. In the UK publichousing context, the highrise is a project that originally triggered enthusiasm but came, relatively quickly, to be met with scepticism. Latour speaks of just such a process when thinking of inventions and scientific claims that simply do not take off:

\footnotetext{
If people are not interested, or they do something entirely different with the claim, the spread of a fact or of a machine in time and space does not take place... Theories that had started to infect the world shrink back to become the idée fixe of some lunatic in an asylum... . Established facts are quickly turned into artefacts, and puzzled people ask, 'how could we have believed in such an absurdity'.. . and dissenters who interrupt the spread of any fact or artefact proliferate. ${ }^{72}$
}

In the UK large numbers of state-funded residential highrises have already been designated as 'redundant' and demolished; with the increasingly market-linked logic of social housing management of this stock, it is likely that such decisions will continue.

I want to get closer to the UK highrise story in which, if you like, a big thing 'shrinks back'. I want to do this by, once again, taking seriously smaller details, albeit details associated with a dramatic and now emblematic event that has been stitched into the big story of the failure of the highrise in the West: this being the collapse of Ronan Point, Canning Town (in what was then the London Borough of Newham) (Figure 4). Ronan Point was the second of nine identical blocks planned for completion in the postwar housing construction programme undertaken in the borough. It comprised 22 floors of flats built in the then innovative Larsen Neilsen prefabricated concrete panel system. Construction began on 25 July 1966 and was completed by March 1968, 


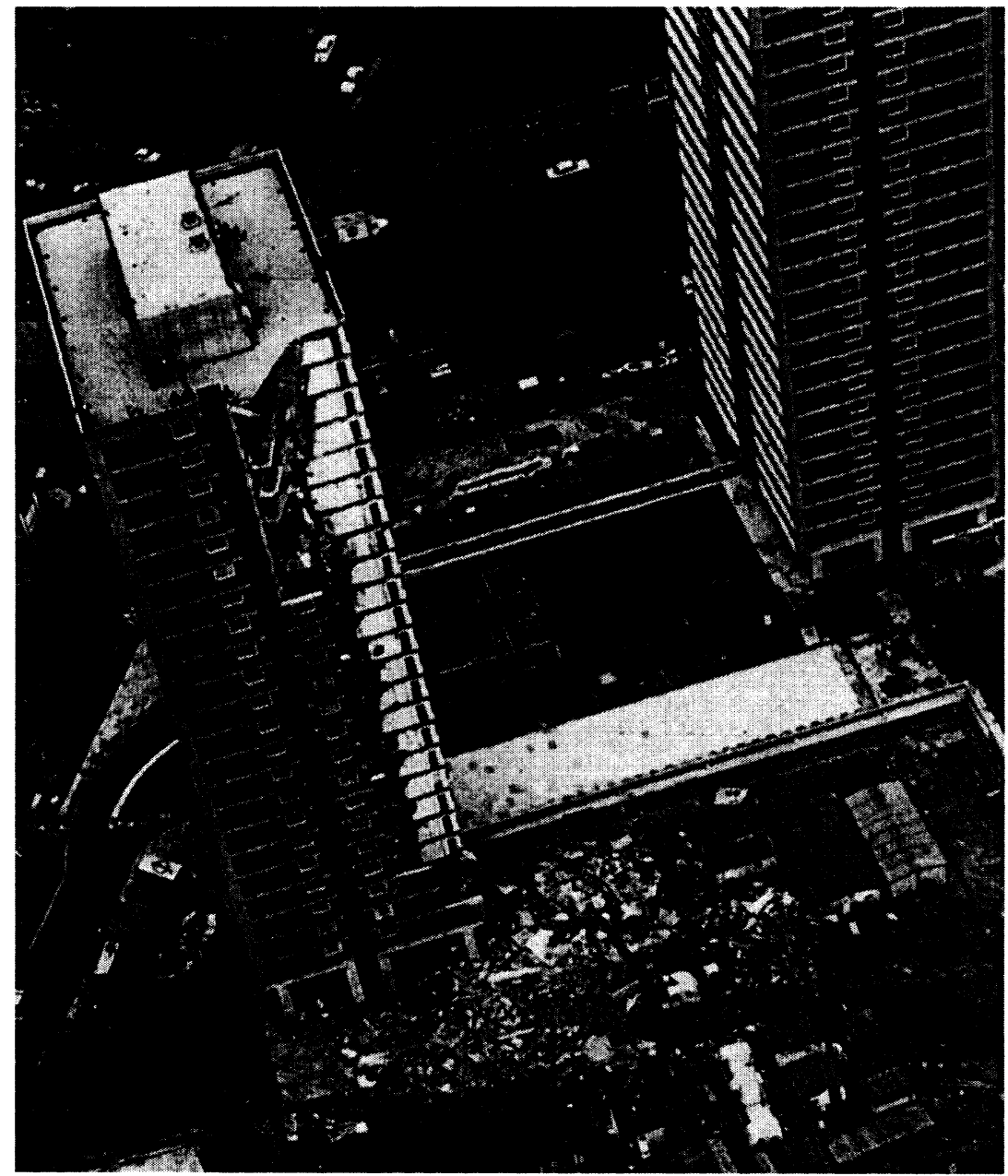

FIGURE 4 The collapsed south-east corner of Ronan Point, following the gas explosion. (Source: $\mathrm{H}$. Griffiths et al., Report of the inquiry into the collapse of flats at Ronan Point, Canning Town, Ministry of Housing and Local Government, 1968.)

with tenants moving in almost immediately. At approximately $5.45 \mathrm{a} . \mathrm{m}$. on Thursday 16 May 1968, just two months after the blocks started to be occupied, there was an explosion in one of the flats on the south-east corner of the block. The explosion blew out the non-load-bearing face walls but also an external load-bearing flank wall, causing a progressive collapse of the floor and wall panels of that corner of the block right down to the level of the podium. Four people died and 17 were admitted to hospital with injuries, with one of the injured dying later. ${ }^{73}$ What do we start to see when we get closer to this event: when we move past the emblematic image of collapse depicted in the newspapers of the time, and go inside the building and enter Flat 90 , the 
home of Mrs Ivy Hodge, and encounter the thing at the centre of this disastrous event, Mrs Ivy Hodge's gas cooker?

System failures or explosion has commonly been used within the field of science and technology studies as a way of investigating how things normally hold together and, in their terms, sustain the machinic qualities of a 'black box'. An explosion or a system failure marks a point where the varied allies that work to hold something together stop working together. At least some of that work on disasters and system failures has dealt with the character of the explanations that are given, often through the formal procedure of the public inquiry. ${ }^{74}$ These explanatory stories often have a spatial character. It is not only that they happen somewhere, but that the character of explanation is often a search, as Law reminds us, for where responsibility lies. $^{75}$

This matter of where responsibility lay was central to the inquiry into the Ronan Point collapse. Was it something Mrs Ivy Hodge did with her gas cooker? Was it something that $\mathrm{Mr}$ Charles Pike, her friend who fitted the gas cooker, did not do right? Was it something to do with the system of provision of 'town gas'? Was it something to do with the way the building was built: the materials used, or the inadequate following of manufacturers instructions for the Larsen Neilsen system, which had never before been used on such a tall building? In short, was this a systemic (big) failure involving many things or the fault of one small thing? In this sense the Ronan Point inquiry is quite literally an inquiry into the scale of something.

The inquiry delivers a story of the machinic quality of the highrise, outlining in great detail the systems, technologies, individuals and materials that come together to produce the building and, subsequently, its failure. Latour, as it happens, gives us a very nice description of a machine, by contrasting it to a tool. 'A tool', he specifies, 'is a single element held directly in the hand of a man or a woman': 'Useful as tools are, they never turn $\mathrm{Mr}$ or Ms Anybody into Mr or Ms Manybodies! ${ }^{76}$ This question of tool versus machine was central to the inquiry and the question of where blame could be laid. And central to determining that fact was whether the damage was the result of the explosion alone, or the result of events prior or subsequent to the explosion.

In the Inquiry into Ronan Point both Mrs Ivy Hodge and her handyman friend Mr Charles Pike were kept in the position of $\mathrm{Mr}$ and Mrs Anybody: small users of tools. Although the fact of her lighting a match to boil her kettle ignited the gas explosion, Mrs Ivy Hodge was quickly seen as a victim rather than perpetrator of this disaster. Indeed, Mrs Hodge and what was left of her kitchen soon became important evidentiary points in the careful forensic efforts that constructed the story of 'where blame lay': 'Three biscuit tins, which Mrs Hodge said she kept in the kitchen cupboard, were recovered from the debris. They were charred and buckled and one contained the remnants of burnt cake. ${ }^{77}$ Experimental tests were carried out on the tins to ascertain the levels of pressure needed to produce the buckling they exhibited. And Mrs Hodge's own (still alive and still pretty much intact) body provided additional evidence about the size of the explosion. The fact that her eardrums were not broken 
assisted greatly in providing the inquiry with a quantified measure of the pressure created by the ignited gas.

Mr Pike was not so lucky. As an unqualified DIY-er who fitted the cooker as a favour to Mrs Hodge, his workmanship and his tools came under close scrutiny. He explained in detail to the inquiry how he fitted the cooker, the pipes he used, the elbow joints, the brass connectors, the asbestos string, and his use of a controversial Stillson pipe wrench. ${ }^{78}$ The Stillson wrench in the hands of Mr Pike was a potential candidate for the matter of 'where to lay blame' because there was a risk of breaking the brass connector by over-tightening. As it turned out, Mr Pike said he knew of such risk and had not used the Stillson, but a pair of pipe grips. This explanation was accepted by the inquiry, although not simply on trust, for the marks left on the brass connecter were checked and found to confirm Mr Pike's version of events (Figure 5). Indeed, by the time the report was written it was made clear on the opening pages that Mr Pike and his DIY gas-fitting efforts had nothing at all to do with the disaster: 'let it be said immediately that it has been shown that no blame for this disaster attaches to him. ${ }^{, 79}$

Where did blame attach, according to the inquiry? The blame for this disaster came to lay in the hands of 'Mr and Mrs Manybody'. The disaster, in the first instance, was divided into two events: the explosion and the subsequent collapse. The explosion was, according to the inquiry, 'the result of an unusual and unhappy combination of events unlikely to be repeated in the future, and for which no blame attaches to those concerned with the construction of Ronan Point or the installation or use of any of the gas fittings therein'. What appears to be a big event, and those immediately implicated in setting it off, are here positioned as small. The collapse is another matter. It was considered to be an outcome inherent to a 'weakness' in the design of the building. This said, the report quickly added:

It was a weakness against which it never occurred to the designers of this building that they should guard. They designed a building they considered safe for all normal uses; they did not take into account the abnormal. They never addressed their minds to the question of what would happen if for any reason one or more of the load-bearing members should fail. ${ }^{80}$

But has blame really found a home now? Not quite, for the designers too were, it seems, as much 'victims' as Mrs Ivy Hodge and the others who lost their lives and their homes. The designers, the inquiry notes,

fell victims, along with others, to the belief that if a building complied with the existing Building regulations and Codes of Practices it must be deemed to be safe. Experience has shown otherwise. We are, it concludes, not concerned to point the finger of blame specifically at the designers of Ronan Point but to ensure that the eyes of all may be opened in the future. ${ }^{81}$

In short, the Inquiry into the collapse of flats at Ronan Point secured the systemic character of this exceptional event. A story that might have been about a Mr Anybody and his tool becomes officially one about Mr Manybody. And in that translation, the building and its many makers become an emblematic point in the big story of the demise of the highrise as a sanctioned housing type in the West. 

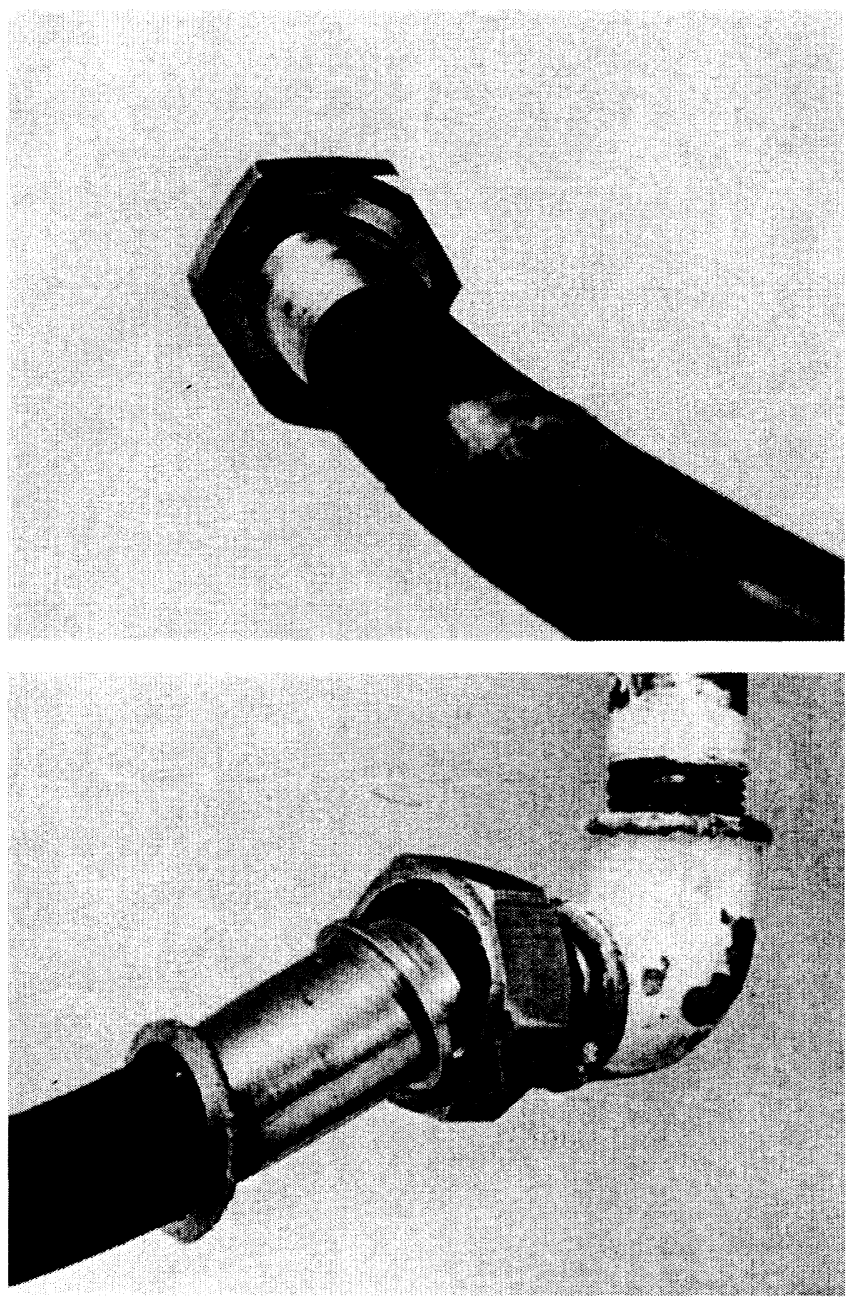

FIGURE 5 The type of gas pipe and elbow joint with which Mr Pike, Mrs Hodge and the fortunes of the highrise in Britain became entangled. (Source: H. Griffiths et al., Report of the inquiry into the collapse of flats at Ronan Point, Canning Town, Ministry of Housing and Local Government, 1968.)

\section{Conclusion}

The explanatory openings produced by theories of performativity and social studies of technology and science have, for better or worse, fashionably or favourably, infiltrated a range of geographies. The emergent critical geographies of architecture provide suggestive pathways for scholarship of this kind, and this paper attempts to extend that scholarship by opening out the intellectual space created when we hesitate around using such terms as architecture. Thinking instead of one 
particular 'big thing', the modernist residential highrise, I have sought to consider the precarious conditions of alliance that allow it to cohere (or not) into a built form, housing, architecture. Further, the deliberately 'flat' descriptive terms of 'big' and 'thing' have been used to take the object of my attentions out of a preexisting scripting as an example of a globalized architectural form. Thinking of buildings or architecture as things, reminds us to always ask: how is this assemblage able to lay claim to the idea of being architecture or a building, and what work is needed for it to sustain that claim materially? This allows the various human and non-human allies that create building events to come into view, including the varied fortunes of sustained materialization as well as dematerilaization. Using the term 'big' similarly allowed me to start to interrogate the complexity of processes by which an apparently big thing (very tall, very global) replicates itself, thereby producing a 'big' effect. I have argued that the making of repetition - or, more precisely, repeated instances in many different contexts - requires variance, different assemblages of allies in different settings. I have also suggested that divisions between big and small, or global and local, are themselves relational effects, and attending to these is a key responsibility of the work of geography. Along the way, I hope I have reiterated the value of one of the foundational methodological commitments of cultural geography - which is the imperative to attend to the small, the minor and the exceptional in the making of our 'big' geographies.

\section{Acknowledgements}

This paper was originally presented as the cultural geographies Annual Lecture, at the 2005 Meeting of The Association of American Geographers, Denver. I would like to thank Mona Domosh and Phil Crang for that opportunity. I would also like to acknowledge the valuable input of my colleagues on the highrise project: Stephen Cairns, Ignaz Strebel and Paul Anderson. This research upon which this paper is based is supported by the Arts and Humanities Research Council (Grant No. APN18420).

\section{Notes}

${ }^{1}$ C. Nash and J.M. Jacobs, 'Too little, too much: cultural feminist geographies', Gender, place and culture 10 (2003), pp. 265-279; K. Anderson, M. Domosh, S. Pile and N. Thrift, eds, Handbook of cultural geography (London, Sage, 2003), p. 1.

${ }^{2}$ M. Crang, Cultural geography (London, Routledge, 1998); D. Mitchell, 'Review of Mike Crang (1998) Cultural geography', Environment and planning D: society and space 17 (1999), p. 498. See also N. Thrift 'Introduction: dead or alive?', in I. Cook, D. Crouch, J. Ryan and S. Naylor, eds, Cultural turns/geographical turns (Harlow, Longman, 2000), pp. 1-7; J.D. Dewsbury and N. Thrift, 'Dead geographies - and how to make them live again', Environment and planning D: society and space 18 (2000), pp. 411-32. 
3 See C. Barnett, 'The cultural worm turns', Antipode 30 (1998), pp. 379-9595; C. Barnett, 'Cultural twists and turns', Environment and planning D: society and space 16 (1998), pp. 631-4.

4 L. Lees 'Towards a critical geography of architecture: the case of an ersatz colosseum', Ecumene 8 (2001), pp. 51-86; L. Jenkins, 'Geography and architecture: 11, Rue du Conservatoire and the permeability of buildings', Space and culture 5 (2002), pp. 222-36; M. Llewellyn, "Polyvocalism and the public: "doing" a critical historical geography of architecture', Area 35 (2003), pp. 264-71; M. Llewellyn, "Urban village" or "white house": envisioned spaces, experienced places, and everyday life at Kensal House, London, in the 1930s', Environment and planning D: society and space 22 (2004), pp. 229-49; D. McNeill, 'Skyscraper geography', Progress in human geography 29 (2005), pp. 41-55. An equally explicit, but theoretically divergent, concern with geography and architecture sustains itself in the work of Larry R. Ford: 'Building biographies: to know cities from the inside out', Geographical review 91 (2001), pp. 380-87; 'Architecture and geography: toward a mutual concern for space and place', Yearbook of the Association of Pacific Coast Geographers 46 (1984), pp. 7-33.

5 F. Kniffen, 'Folk housing: key to diffusion', Annals AAG 55 (1965), pp. 549-77; J.B. Jackson, 'Human, all too human geography', Landscape 2 (1952), pp. 2-7.

6 J. Law, 'After ANT: complexity, naming and topology', in J. Law and J. Hassard, eds, Actor Network Theory and after (Oxford, Blackwell, 1999), p. 4.

7 A.D. King, The bungalow: the production of a global culture (London, Routledge \& Kegan Paul, 1984); A.D. King, Spaces of global cultures: architecture and urban identity (London, Routledge, 2004).

${ }^{8}$ See, as examples only, J. Holston, The modernist city: an anthropological critique of Brasilia (Chicago, University of Chicago Press, 1989); M. Crinson, Empire building: Victorian architecture and orientalism (London, Routledge, 1996); J.M. Jacobs, Edge of empire: postcolonialism and the city (London, Routledge, 1996); M. Crinson, Modern architecture and the end of empire (Aldershot, Ashgate, 2003).

9 D. R. Holmes and G. E. Marcus, 'Cultures of expertise and the management of globalization: toward the re-functioning of ethnography', in A. Ong and S. J. Collier, eds, Global assemblages: technology, politics and ethics and anthropological problems (Oxford, Blackwell, 2004), pp. 235-52. See also K. Olds, 'Globalizing Shanghai: the "Global Intelligence Corps" and the building of Pudong', Cities 14 (1997), pp. 109-23; B. Czarniawska, A tale of three cities: on the glocalization of city management (Oxford, Oxford University Press, 2002).

${ }^{10}$ C. Philo, 'Foucault's geography', Environment and planning D: society and space 10 (1992), pp.158-9, drawing on J. Baudrillard, 'Forget Baudrillard: an interview with S Lotringer', in J. Baudrillard, Forget Foucault (New York, Columbia University Press, 1987), p. 126.

$11 \mathrm{~J}$. Baudrillard, Revenge of the crystal: selected writings on the modern object and its destiny, 1968-1983 (London, Pluto Press, 1999).

12 S. Cutter, R. Golledge and W.L. Graf, 'The big questions in geography', Professional geographer 54 (2002), p. 305.

13 M. C. Boyer, 'Meditations on a wounded skyline and its stratigraphies of pain', in M. Sorkin and S. Zukin, eds, After the World Trade Centre: rethinking New York City (New York, Routledge, 2002), p. 109.

14 A.L. Huxtable, The tall building artistically reconsidered: the search for a skyscraper style (New York, Pantheon Books, 1984), p. 11. 
15 Perhaps this is a symptom of what Lewis Mumford diagnosed when writing, in the 1930s in one of his 'Skyline' articles in the New Yorker, about another tall building, the Rockefeller Centre: 'the central building is very big. And when one has said this, one has said almost everything.' Cited in Boyer, 'Meditations', p. 14.

${ }^{16}$ See as examples of the use of such illustrations: J.O.M. Broek and J.W. Webb, A geography of mankind (New York, McGraw-Hill, 1968); J.E. Spencer and W.L. Thomas, Introducing cultural geography, 2nd edn (New York, Wiley, 1978).

17 J. Gottman, 'Why the skyscraper?', Geographical review 56 (1966), p. 190.

18 L.H. Sullivan, 'The tall building artistically considered' (Lippincott's, 1896), repr. in Kindergarten chats and other writings (New York, Dover, 1980), p. 202.

19 M. Domosh, 'The symbolism of the skyscraper: case studies of New York's first tall buildings', Journal of urban history 14 (1988), pp. 320-45; M. Domosh, 'Imagining New York's first skyscrapers, 1875-1910', Journal of historical geography 13 (1987), pp. 233-48.

20 L.R. Ford, 'The diffusion of the skyscraper as an urban symbol', Yearbook of the Association of Pacific Coast Geographers 35 (1973), pp. 49-60; L.R. Ford, 'The highrise in city structure and urban images: a cross-cultural comparison between Argentina and the American Midwest', Geographical survey (Apr. 1972), pp. 1-23; L.R. Ford, Cities and buildings: skyscrapers, skidrows, and suburbs (Baltimore, Johns Hopkins University Press, 1994).

21 Gottman, 'Skyscraper', 190.

22 A.D. King, 'Worlds in the city: Manhattan transfer and the ascendance of spectacular space', Planning perspectives 11 (1996), p. 97. See also King, Global culture, pp. 3-22. In a similar vein, Tim Bunnell has given specificity to such processes through his detailed account of the role the Petronas Twin Towers (for a short while the world's tallest building) in expressing the aspirational 'world class' status of Malaysia. See T. Bunnell, 'Views from above and below: the Petronas Twin Towers and/in contesting visions of development in contemporary Malaysia', Singapore journal of tropical geography 20 (1999), pp. 1-23.

${ }^{23}$ King, Global cultures, p. 42

${ }^{24}$ R. Koolhaas, Delirious New York: a retroactive manifesto for Manbattan (New York, Monacelli Press, 1994), p. 255. See also D. Pinder, Visions of the city (Edinburgh, Edinburgh University Press, 2005), pp. 89-100.

25 P. Rabinow, French modern: norms and forms of the social environment (Chicago, University of Chicago Press, 1989), pp. 320-58.

${ }^{26}$ See J.M. Jacobs 'Hybrid highrises', in J. Barrett and C. Butler-Bowdon, eds, Debating the city: an anthology (Sydney, Historic Houses Trust of NSW, 2000), pp. 13-20, for a fuller discussion of the hold that this image of repetition and sameness has had on revisionist planning discourse.

27 A. Appadurai, 'Grassroots globalization and the research imagination', Public culture 12 (2000) p. 6.

28 Ibid., p. 18.

29 S.J. Collier and A. Ong, 'Global assemblages, anthropological problems', in Ong and Collier, Global assemblages, p.11.

${ }^{30}$ King, Global cultures; Crinson, Empire.

31 D. McNeill, 'Skyscraper geography', Progress in buman geography 29 (2005), p. 41.

32 Notable studies on highrise public housing in this tradition include: P. Jephcott, Homes in bigh flats (Edinburgh, Oliver \& Boyd, 1971); O. Newman, Defensible space: crime prevention through urban design (New York, Macmillan, 1972); R. Hassan, Families in flats: a study of low income families in public housing (Singapore, Singapore University Press, 1977); D. Drakakis-Smith, High society: housing provision in Hong Kong (Hong Kong, University 
of Hong Kong Press, 1979); J. Ash, 'The rise and fall of high-rise housing in England', in C. Ungerson and V. Karn, eds, The consumer experience of bousing: cross-national perspectives (London, Gower, 1980), pp. 93-123; A. Coleman, Utopia on trial: vision and reality in planned housing (London, Shipman, 1985); B.-H. Chua, Political legitimacy and bousing: stakebolders in Singapore (London, Routledge, 1997); B. Yuen, 'Safety and dwelling in Singapore', Cities 21 (2004), pp. 19-28; B. Yuen, 'Romancing the high-rise in Singapore', Cities 22 (2005), pp. 3-13. It could further be argued that the sub-disciplinary field of environmental psychology was consolidated by the highrise 'problem'. See e.g. L. Yancey, 'Architecture, interaction and social control: the case of a large-scale public housing project', Environment and behaviour 3 (1971), pp. 3-21; W S. Kaplan and R. Kaplan, eds, Humanscape: environments for people (North Scituate, MA., Duxbury Press, 1978); S. Saegert, 'High-density environments: their personal and social consequences', in A. Baum and Y.M. Epstein, eds, Human response to crowding (Hillsdale, NJ, Erlbaum, 1978), pp. 257-81.

33 Rabinow, French modern, p. 343.

${ }^{34}$ L. Sandercock, Towards Cosmopolis: planning for multicultural cities (Chichester, Wiley, 1998)

35 Ibid., p. 23.

36 Ibid., p. 24. There have been others, particularly within feminist geography and planning, who have elaborated similar psychoanalytic accounts of the tall building. See e.g. M. Leiris, 'Skyscraper', in G. Bataille, ed., Enclyopaedia acephalica (London, Atlas Press, 1995), pp. 6972; D. Hayden, Redesigning the American dream: the future of bousing, work and family life (New York, Norton, 1984); M. Morris, 'Great moments in social climbing: King Kong and the human fly', in B. Colomina, ed., Sexuality and space (Princeton, NJ, Princeton University School of Architecture, 1992), pp. 1-51; B. Hooper, 'Urban space, modernity, and masculinist desire: the utopian lusts of Le Corbusier', in A. Bingaman, L. Sanders and R. Zorach, eds, Embodied utopias: gender, social change, and the modern metropolis (London, Routledge, 2002), pp. 55-79.

37 Le Corbusier, Urbanisme (Paris, Crès, 1925) p. 177, quoted in R. Fishman, Urban utopias in the twentieth century: Ebenezer Howard, Frank Lloyd Wright, Le Corbusier (Cambridge, MA, MIT Press, 1982), pp. 192-3.

${ }^{38} \mathrm{HRH}$ The Prince of Wales, A vision of Britain: a personal view of architecture (London, Doubleday, 1989).

39 C. Jencks, The language of post-modern architecture (New York, Rizzoli, 1987). See for an alternative perspective, E. Birmingham, 'Reframing the ruins: Pruitt-Igoe, structural racism, and African American rhetoric as a space for cultural critique', Journal of western communication 63 (1999), pp. 291-309.

${ }^{40} \mathrm{~N}$. Thrift, ' "Not a straight line but a curve", or, cities are not mirrors of modernity', in D. Bell and A. Haddour, eds, CityVisions (London, Prentice Hall, 2000), pp. 233-63.

${ }^{41}$ B. Latour, 1993, We have never been modern (Hemel Hempstead, Harvester-Wheatsheaf, 1993), p. 48, quoted in Thrift, 'Modernity', pp. 234-5.

42 Ibid., p. 234.

${ }^{43}$ Lees, 'Architecture', p. 53.

44 Llewellyn, 'Polyvocalism'.

45 Jenkins, 'Architecture', p. 223.

$46 \mathrm{Ibid}$., p. 225. Jenkins goes on to point out that the materiality of buildings, or more precisely its façade, are often used analytically simply as an example of 'the canon of a specific architect or stylistic movement or lineage'.

47 Ibid., p. 226. 
48 J. Law and A. Mol, 'Notes on materiality and sociality', Sociological review 43 (1995), p. 274, quoted in Jenkins, 'Architecture', p. 230.

49 As Nick Bingham and Nigel Thrift note, Latour thought not of the 'Euclidean house' but of the 'place-event', that unique assemblage of acts of timing and spacing which work to bring the house-thing into being (or not). See N. Bingham and N. Thrift, 'Some new instructions for travellers: the geography of Bruno Latour and Michel Serres', in M. Crang and N. Thrift, eds, Thinking space (London, Routledge, 2000), p. 288.

50 S. Brand, How buildings learn: what happens after they're built (New York, Viking, 1994).

${ }^{51} \mathrm{My}$ intention here is not to reread architectural design as event, as is the sense with Bernard Tschumi's notion of architecture as a framework for constructed situations. See B. Tschumi, Event-cities (Cambridge, MA, MIT Press, 1994); Event-cities 2 (Cambridge, MA, MIT Press, 2001); Event-cities: concept vs. context vs. content: no. 3 (Cambridge, MA, MIT Press, 2005).

52 OMA, R. Koolhaas and B. Mau, SMLXL (Rotterdam, 010 Publishers, 1995), pp. 497-9. Indeed, in bigness, Koolhaas (p. 501) reminds us, the distance between core and envelope increases to the point where the façades can no longer reveal what happens inside and become 'agents of disinformation' and the city becomes an 'accumulation of mysteries'.

53 Ibid., pp. 513-14.

${ }^{54}$ E. Grosz, 'Notes on the thing', in J. Ockman, ed., The pragmatist imagination: thinking about 'things in the making' (New York, Princeton Architectural Press, 2000), pp. 156-7.

55 P. Blackie, 'The theory of spatial diffusion of innovations: a spacious cul-de-sac', Progress in buman geography 2 (1978), pp. 268-95.

56 B. Latour, Science in action: how to follow scientists and engineers through society (Milton Keynes, Open University Press, 1987), p. 133.

57 Ibid. (emphasis original).

$58 \mathrm{~N}$. Thrift, 'It's the little things' in K. Dodds and D. Atkinson, eds, Geopolitical traditions: $a$ century of geopolitical thought (London, Routledge, 2000), p. 380.

$59 \mathrm{~J}$. Law, 'And if the global were small and non-coherent? Method, complexity and the baroque', Environment and planning D: society and space 22 (2004), p. 13.

${ }^{60}$ Ibid., p. 20.

61 Ibid., p. 24.

62 M. Serres, Hermes: literature, science, philosophy, (Baltimore, Johns Hopkins University Press, 1982), p. 53, quoted by Bingham and Thrift, 'New instructions for travellers', p. 288.

${ }^{63}$ Law, 'Baroque', p. 25.

64 The content of this section is drawn in part from J.M. Jacobs, 'The highrise leap: suicide and modernity in post-independence Singapore', Singapore journal of tropical geography (forthcoming).

65 D.P. Gaonkar, 'On alternative modernities', Public culture 11(1999), p. 2.

66 The analytic frame of 'alternative modernities' does not deny networks of connectivity or points (and nodes) of convergence. But it does not necessarily see these as part of an always hierarchical and always unidirectional account of transnational connection and transformation, as they might have been viewed through the lens of diffusionist understandings of social transformation.

67 Gaonkar, 'Modernities', p. 16.

68 R. Hassan, 'Some sociological implications of public housing in Singapore', South-East Asian journal of sociology 2 (1969), pp. 23-6; R. Hassan and K.L. Tan, 'Suicide in Singapore: a sociological analysis', South-East Asian journal of sociology 3 (1970), pp. 13-26; R. Hassan, 'Social and psychological implications of high population density', University of Singapore, Department of Sociology Working Paper 47 (1975); R. Hassan, Families in flats: a study of low 
income families in public housing (Singapore, Singapore University Press, 1977); R. Hassan, A way of dying: suicide in Singapore (Kuala Lumpur, Oxford University Press, 1983).

69 B.H. Chia, Suicidal behaviour in Singapore, (Tokyo, SouthEast Asian Medical Information Centre, 1981).

70 Ibid., p. 118.

71 Ibid., p. 123.

72 Latour, Science in action, p. 121.

$7373 \mathrm{H}$. Griffiths, A. Pugsley and O. Saunders, Report of the inquiry into the collapse of flats at Ronan Point, Canning Town, Ministry of Housing and Local Government (London, Her Majesty's Stationery Office, 1968), pp. 12, 17.

74 J. Law, 'Ladbroke Grove, or how to think about failing systems' (Lancaster University, Centre for Science Studies, 2003), http://www.comp.lancs.ac.uk/sociology/papers/Law-LadbrokeGrove-Failing-Systems.pdf; J. Law, 'Disasters, a/symmetries and interferences' (Lancaster University, Centre for Science Studies, 2003), http://www.comp.lancs.ac.uk/sociology/ papers/Law-Disasters-Asymmetries-and-Interferences.pdf.

75 Law, 'Ladbroke Grove', p. 2.

76 Latour, Science in action, p. 129.

77 Griffiths et al., Inquiry, p. 19.

${ }^{78}$ Ibid., pp. 20-21.

79 Ibid., p. 1.

${ }^{80}$ Ibid., p. 4.

${ }^{81}$ Ibid. 